\title{
Strategic Cost Management Practices Adopted by Segments of Brazilian Agribusiness
}

\author{
Marcos Antonio Souza ${ }^{1}$ and Kátia Arpino Rasia ${ }^{2}$ \\ ${ }^{1}$ Universidade do Vale do Rio dos Sinos - Unisinos \\ ¿Universidade Federal de Rio Grande - Furg \\ Brazil
}

\section{Introduction}

The perception that the globalization event creates an increasingly fierce competition between companies is already known by managers and customers (Shank \& Govindarajan, 1997). Like in the other segments, in agribusiness the tougher competition has been one of the inducing vectors, among others, in the search for more effectiveness and efficiency in the use of resources, as a way of ensuring business continuity.

In agribusiness, factors such as scarcity of resources, emergence of new technologies in equipment and supplies, coupled with changes in the eating habit, may also change consumer's expectations if the products become less attractive and/or more expensive. This dynamics involves and guides the competitiveness of agribusiness companies, needing to anticipate trends relating to these issues and taking actions to increase the demand of their products and achieve higher contribution margins (Cyrillo, 2010). In general, globalization impacts the business in terms of both threats and opportunities, whether domestic or foreign. The growth of agribusiness in Brazil led to the expansion of the performance frontiers, making a strong presence in foreign markets, with Brazilian products gaining international prominence and competing favorably with products from other countries (Gasques et al, 2004).

The management process of the organizations demands information from all kinds, financial and non-financial quantitative and qualitative. Among the quantitative information, the ones from cost assume strategic aspect in the analysis of competitiveness and have to face the competition by organizations. From this perspective it is important to understand and analyze the valuable activities of the organization with the external environment, called by Porter (1989) as value chain analysis, unique for each company. This proposed analysis allows to identify the strengths, weaknesses and opportunities for improving business performance based on their processes and costs. For Shank \& Govindarajan (1997), cost management can lead to an effective control of spending and can ensure an advantage against the competition. Costs affect all organizations' areas and activities and are determined by the set of management decisions.

From the 80s, new cost management practices emerged in response to criticism about the usefulness of the available techniques and used ones by the traditional managerial accounting. Those were shaped by a more complex operational environment in which there 
was need for the information to reflect the changes . (Johnson and Kaplan, 1987; JOHNSON, 1992; Bacic, 1994). The commonality in the criticisms, besides the proposition and discussion on specific practices, is the finding that the cost management should also consider environmental factors external to firms, creating a new knowledge field and professional practice called Strategic Cost Management - SCM.

The adoption of strategic cost management practices by the companies has been the subject of several studies at national (Reckziegel, Souza and Diehl, 2007, Marques et al, 2003, Ferreira, Silva and Batalha, 2010; Muniz, 2010, Souza, Collaziol and Damacena, 2010) and international level (Guilding, Cravens and Tayler, 2000; Bowhill and Lee, 2002; Dekker and Smidt, 2003, Waweru, Hoque and Uliana, 2005; Cinquini and Tenucci, 2006; Cadez and Guilding, 2007; Zoysia and Herath, 2007; Noordin, Zainuddin and Tayler, 2009; Angelakis, and Thério Floropoulos, 2010). Based on the findings of these studies, it is observed that the adoption of the strategic cost management practices, when segregated in countries, present higher frequency of use in developed countries like Japan, Italy and United States of North America.

Still, the analysis of the researches' findings shows the lack of studies in the agribusiness companies, despite their social and economic relevance. Thus, the research problem that guides this study is: What best strategic cost management practices are used by segments of agribusiness companies in Brazil?. The overall objective is to identify, in Brazilian agribusiness segment, which practices in strategic cost management are used. The specific objectives are: (a) to identify the practice of cost management highlighted by the literature, (b) to identify the potential benefits, limitations and disadvantages of adopting these practices, (c) to verify the existence of a relationship between the use of SCM practices and the level of competition, (d) to examine the perception of the practices' benefits in those companies with international operations, (e) to identify the degree of difficulties noticed in adopting the surveyed practices.

The study contributes to a complex business segment and still lacking in empirical investigations on the cost management practices. It also meets the recommendations of Callado and Callado (2006), that by highlighting the importance of agribusiness emphasize the paucity of academic studies focused on cost management in firms of this segment. Specifically, the authors show the need of the analysis of cost practices, an important tool for generating information for decision making. Besides this introduction, form the text other four parts: (i) in section two the theoretical framework, (ii) the methodology in section three, (iii) in the fourth section results and the discussion of research findings and (iv) final. Finally, in references are listed the sources used in the research's development and theory.

\section{Theoretical framework}

\subsection{Strategy applied to business management}

Miles and Snow (1978) identified four types of strategy that are distinguished by the corporate behavior of firms: (a) Prospector: corresponds to pioneering companies that want innovation, (b) Defender: used by companies with tight organizational controls of efficiency and quality, (c) Analyzer: combines prospectors' and defenders' features, and (d) Reactor: only reacts to the environment, as if it didn't have its own strategy, and seeks new products 
or markets only when it feels threatened by competitors. The authors emphasize that the chosen strategy must be adapted to the chosen market, with a particular configuration of technology, structure and process, consistent with its market strategy.

Porter (1989) sustains that there are only three successful and internally consistent strategies to achieve better performance than other firms. These generic strategies are: (a) Cost leadership: the company becomes a low-cost competitor in its industry; (b) Differentiation: the company seeks to be unique in its industry, observing some dimensions valued by buyers; (c) Focus: the company is based on the choice of a narrow competitive environment of an industry, selects a segment or group of segments in the industry and tailors its strategy to serve them. For the author these are the viable approaches to deal with competitive forces. However, companies must adopt only one of them, otherwise they would be stuck in the middle ground and without a defense strategy.

To Anthony and Govindarajan (2008), although the definitions on strategy differ, there is agreement that the strategy sets the direction and the plans for achieving the goals. A company develops its strategies combining its core competencies with market opportunities, while observing the risks and weaknesses. In the process of defining the strategies, the environmental analysis seek to identify opportunities and threats. Porter (1986) identifies the existence of five basic competitive forces: (i) the bargaining power of suppliers, (ii) of buyers, (iii) the threat of new entrants, (iv) the threat of substitute products and (v) rivalry among competing firms.

Authors from other areas such as marketing: like Kotler (1998) who defines the typologies in which businesses can be fitted due to its chosen strategy as: (i) leaders, (ii) challengers, (iii) followers and of market niches. A company is a leader when it has relevant participation in the product market and maintains its leadership by changing prices and launching new products. The challengers are those of lower ratings in an industry and they can attack the leader in an aggressively bid. The followers track, copy or improve a product to launch it and get high profits, since it did not incur expenses related to innovation. The ones of market niche create, expand and protect their portions of space.

Because of its operational characteristics, the agriculture and stock-breeding is under pressure by society groups concerned about the impact of its activities on the environment. In this sector, the concern with the environmental impacts that come from its activities has grown. For Marques et al (2003) the negative impacts result in the reduction of biodiversity, erosion and contamination of soil, silting and contamination of water sources, and they possibly cause changes in regional climate. To mitigate these effects, companies must implement environmental strategies. The social benefits offered by companies under the implemented environmental strategy, impact positively over its image. Recognition by society over environmental and socially correct practices of companies can contribute to the brand development and strengthening and its reputation, impacting directly on its sustainability (Thorpe and Prakash-Mani, 2003).

\subsection{The management model as competitive edge}

It is typical of a competitive environment that companies constantly seek to adapt. Also, despite competing in the same segment, organizations adopt and implement different models for managing their business. Although sometimes strategies are similar, only a few 
organizations can achieve their goals. One explanation for this may be because the used management model in the organization does not comply with the requirement imposed by the situation and the environment.

About the management model, Nascimento, Reginato and Lerner (2007) argue that the construction of a well-defined, organized and coordinated structure, to harmonize the performance of activities guided by pre-established conduct rules, may represent difference in terms of competition. The management model, when formalizing the management process - which generally comprises the steps of planning, execution and control - structures and approximates the foundations of strategic cost management. It will be in the management process, in the planning stage - strategic and operational - that strategic goals and strategies of organizational activities will be defined. In order to create interaction and synergy between parts, the management model should establish how the flow of information will happen, the channels of communication, internal controls (among other purposes, to evaluate the performance) and also the formalization of decision making and its models. Therefore, the success of strategic cost management is related to the adequacy of the model management, process management and decision-making process to the needs of the organization.

Frost (1999) points out that managers need support to achieve the highest performance and also have a good understanding of how the performance can be quantified and communicated. In the everyday of organizations, managers are pressured by consumer demand, increased competition and the ever-shrinking time. We live the time that everything has to be done better, faster and cheaper. In this context, it is vital for managers that the company translates its strategy into measurable goals through an appropriate measurement model, readily available by information systems.

Fischmann and Zilber (2008), addressing the issue of evaluation, emphasize that performance indicators emerge as one of the tools that can assist in defining the strategic planning and consequently the determination of business strategies. Thus, according to the authors, it is possible to check the property with which decisions were taken. It is in this environment that the strategic cost management plays an important role, providing information to managers to support the management process and decision making.

\subsection{Agribusiness}

The term agribusiness first came at Harvard University, USA, coined by Professors Davis and Goldberg (1957), based on study from the input-output approach and conceptualized as the total sum of all operations involved in the manufacture and distribution of farm supplies. In this approach, agribusiness is set around the business of agriculture and is the basis of food production. As agriculture could not be considered in isolation, the authors considered it as part of an extensive network of economic agents, starting with the production of raw materials, industrial processing, storage and distribution of agricultural products and derivatives.

Over the time, changes in the way of life bring out changes in consumer eating habits. Zuin and Queiroz (2006) found that the people's short available time for meals triggered the need for rapid preparation of food. As a result, there is need and demand for ready-to-eat or semi-ready-to-eat products, causing changes in products, production processes and forcing 
companies to use new production technologies. On the other hand, the failure to adapt to new corporate standards and expectations demanded by the consumer, can result in reductions in volumes and lower profit margins.

In the U.S., Jackson and Mitchell (2009) observed the increasing vertical integration of agribusiness food chain. However, they noticed negative effects of the near price monopoly featured by companies that have the power inside the chain. In this scenario, the authors believe that the power imbalances in food production and speculation in agricultural commodity markets should be analyzed for representing an obstacle to the operation of the food chain.

The dynamics of agribusiness is driven by the pursuit for competitive advantage, mainly occurring through vertical integration, (Silva and Batalha, 2010, Jackson and Mitchell, 2009; Callado and Callado, 2009; Azevedo, 2010). Vertical integration is defined by Porter (1989) as the division of activities between a company and its suppliers, channels and buyers, so a company can buy components rather than manufacture them. Then, a way the company can differ from others is assuming a greater number of buyer activities. For Loturco (2008) the growth of Brazilian agribusiness is in the process of modernization, with products competing in national and international markets. Brazil is asserting itself as a major supplier of food and raw materials of natural origin [commodities] in the international market (Lima et al (2009). For the author, the coverage and social and economic impacts of Brazilian agribusiness is impressive. Around 5000 cities depend directly on the agribusiness, contributing with $26.5 \%$ in the formation of the country's gross national product. Sobral (2008) adds that agribusiness in Brazil is growing due to its favorable climatic conditions and prices of major agricultural commodities in great demand international market.

Brazil, according to IICA (2009), takes the first place in the production of biofuels, representing $36 \%$ of world production. The Brazilian coffee production is also outstanding, reaching $34 \%$ of the world's, reaching the first place, followed by Vietnam (14\%), Colombia (9\%), Indonesia (5\%), Ethiopia (5\%), India (4\%) and Mexico (3\%). Still according to data from IICA (2009), Brazil is the largest producer of oranges in the world context and accounts for $33 \%$ of production. The U.S. ranks second in world production of oranges, followed by China (12\%), EU (11\%), Mexico (8\%) and Egypt (7\%). Brazil is number two in world production of soybeans, with $26 \%$, followed by Argentina (20\%) and China (7\%). According to CNA (2010), Brazilian agriculture and livestock breeding ended 2009 with production equivalent to $\mathrm{R} \$ 718$ billion, showing a decrease of $\mathrm{R} \$ 46.6$ billion compared to the previous year. Such reduction is equivalent to a loss of $6 \%$ in the share of agriculture and livestock breeding in the shaping the country's Gross National Product. In the National Food and Nutritional Security Council - CONSEA (2008), discussions are that the expansion of biofuel production can affect food production in Brazil, especially in the state of São Paulo. According to this group, there is need of public policies to harmonize food energy production, so that the crops won't lose space for the production of biofuels.

\subsection{Strategic cost management}

Simmonds (1981, p.26), in a seminal article on the subject states:

Strategic Management Accounting can be defined as the provision and analysis of management accounting data about a business and its competitors for use in developing 
and monitoring the business strategy, particularly relative levels and trends in real costs and prices, volume, market share, cash flow and the proportion demanded of a firm's total resources.

The author also states that SCM is not the redefinition of business, planning or marketing functions inside the company. Also, it is emphasized that the management accounting skills are essential. The use of traditional management accounting techniques combined with contemporary ones is adopted by Shank and Govindarajan (1997).

An important component of management information systems of any organization is the accounting system. Assuming the importance of management information required by managers according to Simmonds (1981), it is pertinent the alert from Johnson and Kaplan (1992): an inefficient accounting system can undermine both the development of superior products or the improvement of processes and marketing efforts. Kaplan and Norton (1997) and Shank and Govindarajan (1997), in general, are the most often mentioned authors when the topic is seeking competitive advantage with the use of cost information, among others. Also, it has been credited that as consequence of the criticisms over accounting (in particular by Johnson and Kaplan, 1992), there were new practices, approaches and procedures for costs considered more appropriate to the new demands of management. The main criticism - widely accepted and disseminated by a majority of authors - is based on the argument that the practices of cost accounting and management, still in use today, were developed to a reality of business and technology which no longer exists.

The SCM approaches by other authors, in general, are in accordance to the proposal of Simmonds (1981). Bacic (2009) sustains that management accounting should be considered within a framework that recognizes the impact of competition and strategy, noting the criteria and business's needs. In the same way, to Blocher et al (2007) since strategic factors are growing in importance for management, cost management has transformed its traditional role of cost of product and operational control into a broader and strategic focus. Thus, for the authors, strategic cost management is the development of cost management information in order to facilitate the primary function of management: strategic management. As expected from an evolutionary process, over the years specific cost management practices were developed and incorporated into SCM.

\subsection{Analyzed strategic cost management practices}

The practices of strategic cost management lead to information that can contribute so that the company can succeed in assuring competitive advantage. For Hansen and Mowen (2001), strategic cost management uses cost information to develop and identify superior strategies, capable of producing a sustainable competitive advantage. The analyzed SCM practices were classified according to three factors discussed in the study of Cinquini and Tenuci (2006), shown in Figures 1, 2 and 3.

In Figure 2 are listed the practices of Factor 2 (Processes and Activities) and Factor 3 (Clients).

In Figure 3 are listed the practices related to Factor 4 (Competitors).

The external analysis of costs comes from the recognition that only internal efficiency is no longer sufficient for the effectiveness of the company. It includes two approaches of 
data collection and analysis: (1) competitors, about best practices in processes, product attributes, accounting data, or costs, (2) it involves costs that focus on the processes and activities of customers and suppliers, constituted by the sequence of actions throughout the production workflow, from acquisition of raw materials to product delivery to consumers.

\begin{tabular}{|l|l|}
\hline SCM Practices & Main Characteristics \\
\hline $\begin{array}{l}\text { Cost of Product Life } \\
\text { Cycle - CPLC }\end{array}$ & $\begin{array}{l}\text { The CPLC considers all the necessary steps of the product, from } \\
\text { design to delivery and installation of the finished product. It } \\
\text { evaluates the cost of products while designing, producing, } \\
\text { distributing, consuming and disposal phase. }\end{array}$ \\
\hline $\begin{array}{l}\text { Total Cost of } \\
\text { Ownership - TCO }\end{array}$ & $\begin{array}{l}\text { It analyzes the cost of purchasing properties or services from a } \\
\text { particular provider. It represents the total of all costs of } \\
\text { properties/ services, from its acquisition to its final consumption } \\
\text { and disposal. }\end{array}$ \\
\hline $\begin{array}{l}\text { Environmental } \\
\text { Costs }\end{array}$ & $\begin{array}{l}\text { Costs incurred because there is poor environmental quality or } \\
\text { because it can exist. They can be classified into four categories: (i) } \\
\text { prevention costs, (ii) costs of detection, (iii) internal failure costs } \\
\text { and (iv) external failure costs. }\end{array}$ \\
\hline Kaizen costing & $\begin{array}{l}\text { It means continuous improvement. It is a management technique } \\
\text { from which managers and staff are committed to a program of } \\
\text { continuous improvement in quality and other critical factors of } \\
\text { success. }\end{array}$ \\
\hline Intangible costs & $\begin{array}{l}\text { Practice of hidden cost analysis, the result of structural items and } \\
\text { inefficiency of management; deriving from the existence of } \\
\text { intangible factors and resulting from the formation of intangible } \\
\text { assets. }\end{array}$ \\
\hline
\end{tabular}

Source: Based on Cinquini and Tenucci (2006).

Fig. 1. SCM Practices, according to Factor 1: Quality

\section{Methodology}

The approach of this research is exploratory because it provides familiarity with the subject - strategic cost management in agribusiness segment firms - and the related problem (Menezes and Silva, 2001). It is also descriptive by highlighting the characteristics of a given population or phenomenon or establishment of a correlation between variables (Gil (2002). The classification is quantitative for the usage of statistical techniques for analysis and interpretation of data. The qualitative aspect is a result of the performed analysis based on quantitative data (Roesch, 2005). This research is also a survey and data were collected via structured questionnaire with closed questions and Likert scale to capture the intensity of the responses. The assertions in the questionnaire concerning to SCM practices were based on the study of Cinquini and Tenucci (2006). As usual, pre-test was conducted with teachers and controllership professionals, whose suggestions and contributions have improved the instrument. 


\begin{tabular}{|c|c|c|}
\hline & SCM Practices & Main Characteristics \\
\hline \multirow{5}{*}{$\begin{array}{l}\text { Factor 2: } \\
\text { Processes and } \\
\text { Activities }\end{array}$} & $\begin{array}{l}\text { Value Chain } \\
\text { Analysis }\end{array}$ & $\begin{array}{l}\text { Practice of monitoring opportunities in bonds with } \\
\text { customers and suppliers. It divides the chain into } \\
\text { relevant strategic activities so that one can } \\
\text { understand the behavior of costs and sources of } \\
\text { differentiation. }\end{array}$ \\
\hline & \begin{tabular}{|l|} 
Activity Based \\
Management (ABM)
\end{tabular} & $\begin{array}{l}\text { Practice developed for the funding and management } \\
\text { of the activities that consume resources; it allows the } \\
\text { identification, reduction or even elimination of } \\
\text { activities that do not generate value to the customer. }\end{array}$ \\
\hline & Target costing & $\begin{array}{l}\text { It determines the cost for a product based on a certain } \\
\text { competitive sale price, and that the product achieves } \\
\text { the wanted profit. It uses Value Engineering to } \\
\text { reduce costs based on the manufacture alternatives. }\end{array}$ \\
\hline & Logistics cost & $\begin{array}{l}\text { Analysis of costs of supply, purchase, distribution } \\
\text { and storage of inputs and outputs. }\end{array}$ \\
\hline & $\begin{array}{l}\text { Analysis of the } \\
\text { Determinants of } \\
\text { Cost }\end{array}$ & $\begin{array}{l}\text { Considered as central points of cost management, } \\
\text { they represent the cause of costs and precede the } \\
\text { effective execution of operations. In general, they are } \\
\text { related to the facilities, technology and complexity of } \\
\text { the activities used in the processes of activities related } \\
\text { to production of properties and services. }\end{array}$ \\
\hline $\begin{array}{l}\text { Factor 3: } \\
\text { Performance } \\
\text { Analysis }\end{array}$ & \begin{tabular}{|l|} 
Indicators and Non- \\
Financial Metrics
\end{tabular} & $\begin{array}{l}\text { Indicators allow the understanding, the } \\
\text { comprehensive analysis of economic and financial } \\
\text { situation of the company and can be applied to all } \\
\text { strategic aspects of analyzed costs in practices of } \\
\text { strategic cost management. }\end{array}$ \\
\hline
\end{tabular}

Source: Based on Cinquini and Tenucci (2006)

Fig. 2. SCM Practices, according to Factor 2: Processes and Factor 3: Performance.

\begin{tabular}{|l|l|l|}
\hline & \multicolumn{1}{|c|}{ SCM Practices } & \multicolumn{1}{c|}{ Main Characteristics } \\
\hline Factor 4 & $\begin{array}{l}\text { Cost Analysis of } \\
\text { Competitors }\end{array}$ & $\begin{array}{l}\text { It collects data to appreciate the value chain of } \\
\text { competitors, transforming them into useful } \\
\text { information to decision-making. }\end{array}$ \\
\cline { 2 - 3 } $\begin{array}{l}\text { Analysis of } \\
\text { Costs }\end{array}$ & $\begin{array}{l}\text { Interorganizational } \\
\text { Cost Management, } \\
\text { GIC }\end{array}$ & $\begin{array}{l}\text { It is the exchange of information between chain } \\
\text { companies to establish improvements to } \\
\text { processes, through partnerships. It uses the } \\
\text { Open-Book Accounting (OBA) for opening the } \\
\text { company's cost information in order to reduce } \\
\text { costs and optimize results. }\end{array}$ \\
\hline
\end{tabular}

Source: Based on Cinquini and Tenucci (2006)

Fig. 3. SCM Practices, according to Factor 4: Competitors.

The sample consists of investigated companies, those belonging to the segments (1) sugar and alcohol and (2) wood, pulp and paper. The sampling used was non-probabilistic and 
the sampling frame were the companies listed (Babbie, 2005) in the Yearbook of Agriculture Exam 2008. After identifying the companies, potential respondents were contacted and 120 emails were sent with the link to the questionnaire. After a few weeks, the companies were contacted again and encouraged to answer. With the return of 34 questionnaires, data collection phase was completed. The return rate was $28.3 \%$ - the average of other surveys of the area. After the collection, the data were tabulated and summarized by using MS-Excel spreadsheets and statistical analysis done by SPSS software. In processing the data, the techniques used were the descriptive statistics - frequency distribution, mean, median and standard deviation - and measures of correlation (Pearson coefficient and ANOVA).

\section{Results and discussion}

\subsection{Description of companies}

The companies in Brazilian agribusiness that took part in this research are part of the segments (i) sugar and alcohol and (ii) wood, pulp and paper. In order to make a description of the respondent companies, they were asked for specific information. The distribution of companies by revenue indicates that $38.2 \%$ of the respondents have annual revenue of up to $\mathrm{R} \$ 500$ million, $29.4 \%$ in the range of $\mathrm{R} \$ 501$ million to $\mathrm{R} \$ 1$ billion and $32.4 \%$ over $\mathrm{R} \$ 1$ billion. As regarding the origin of firms, there is a predominance of Brazilian with $82.3 \%$, most of them (53.6\%) of sugar and alcohol sector. All six international companies operate in the sector of wood, pulp and paper. In relation to the target market, most companies $(94.1 \%)$ operate in the foreign market via exportation. For a significant number of companies in the sugar and alcohol segment, exportation revenues are around $10 \%$ of its total income. In this revenue edge for the foreign market, companies of the wood, pulp and paper sector account for $32.4 \%$ of the sample.

Most companies have a long period of existence, some over 100 years. From 1961 to 1975 was the creation of $30 \%$ of all enterprises. Regarding the location of firms, the prevailing states are São Paulo (35.2\%), Paraná (23.5\%), Alagoas (11.8\%) and Minas Gerais (8.9\%). In São Paulo there is equal division among segments. Among Paranás companies prevail the wood, pulp and paper sector (85\%). The surveyed Alagoas's companies operate only in sugar and alcohol sector. The perception of surveyed managers about the type of competition faced by the companies showed that $44.1 \%$ of them operate in highly competitive markets and $55.9 \%$ in medium competitive markets. In the segment of sugar and alcohol, for the surveyed managers, the highly competition is due to the increase of the demand for biofuels. Analysis undertaken by CONSEA (2008) points out that the increased demand for biofuels has led to expanding the frontiers of sugar cane crops, reducing the areas for food or forcing the displacement to other regions.

\subsection{Analysis of SCM practices}

Table 1 shows that the SCM practices frequently used by companies are (i) the determinants of costs, (ii) value chain analysis, (iii) indicators and non-financial metrics, (iv) target costing, (v) standard cost and (vi) logistics costs.

The practice of analyzing the determinants of cost is often used by all firms surveyed. These findings are justified by the particularities of agribusiness, leading to greater complexity in management (Vilckas and Nantes, 2006). With the technical knowledge on production 
processes, managers need to use management tools to plan the productive activities and add value to products. The value chain analysis is frequently used by $89 \%$ of companies surveyed. This finding is in accordance to the statement of Oliveira and Pereira (2008), for whom the management of agribusiness companies must observe the value chain to differentiate themselves from competitors. Thus, the use of this practice, besides providing a number of reviews, defends the adoption of strategies of differentiation (Porter, 1989).

\begin{tabular}{|l|c|c|c|}
\hline $\begin{array}{l}\text { Strategic Cost Management } \\
\text { Practices }\end{array}$ & \multicolumn{1}{|c|}{$\begin{array}{c}\text { Degree of } \\
\text { Usage of } \\
\text { SCM } \\
\text { Practices }\end{array}$} & $\begin{array}{c}\text { Degree of } \\
\text { Benefits for } \\
\text { SCM } \\
\text { Practices }\end{array}$ & $\begin{array}{c}\text { Degree of } \\
\text { Difficulty in } \\
\text { Adopting } \\
\text { SCM } \\
\text { Practices }\end{array}$ \\
\hline Intangible costs & \multicolumn{3}{|l|}{} \\
\hline Analysis of the Determinants of Cost & 2,26 & 2,56 & 4,00 \\
\hline Value Chain Analysis & 4,59 & 4,56 & 3,06 \\
\hline Cost of Product Life Cycle & 2,47 & 4,41 & 3,09 \\
\hline Activity Based Management (ABM) & 2,26 & 3,71 & 3,35 \\
\hline Environmental Costs & 2,59 & 3,50 & 3,59 \\
\hline $\begin{array}{l}\text { Indicators and Non-Financial } \\
\text { Metrics }\end{array}$ & 4,15 & 4,06 & 3,65 \\
\hline Target Costing & 4,50 & 4,47 & 2,88 \\
\hline Standard Cost & 4,09 & 4,62 & 2,82 \\
\hline Logistics Cost & 4,35 & 4,24 & 2,85 \\
\hline Total Cost of Ownership - TCO & 2,06 & 4,59 & 2,85 \\
\hline Kaizen Costing & 2,06 & 2,91 & 3,79 \\
\hline External Analysis of Costs & 2,79 & 3,12 & 3,74 \\
\hline
\end{tabular}

Source: Research Collected Data

Table 1. Usage, Benefits and Difficulties in Adopting SCM Practices.

The indicators and non-financial metrics are significantly used by $88 \%$ of the companies investigated. For Nakagawa (1991) a management information system which does not incorporate non-financial indicators is weak, which does not occur with significant proportion of respondent companies. Queiroz (2006) states that the information systems of agribusiness companies must demonstrate the large performance of operations in financial and nonfinancial format.

The practice of target costing is used by $94 \%$ of companies, indicating that they consider the price charged by the market as a benchmark for setting their costs (Rocha (1999). The practice of standard costing in $89 \%$ of companies shows that its use and target costing's are complementary, not antagonistic. These findings suggest that there are benefits with the use of standard costing in the control stage, after the planning phase of the product with support the target costing, as proposed in the study of Carastan (1999). Although the literature stresses the importance of $\mathrm{ABC} / \mathrm{ABM}$ to the analysis and value creation in activities (Kaplan and Cooper, 1998, Blocher et al, 2007), only 15\% of companies surveyed use these practices to analyze and measure activities of the production process. 
Diagrammed in Figure 4 is a comparison between the average level of use, benefits and difficulties noticed by managers in relation to the adoption of the practices of SCM, based on a scale from 1 to 51 to 5 ( $1=$ no or no one, $5=$ always or a lot, as appropriate).

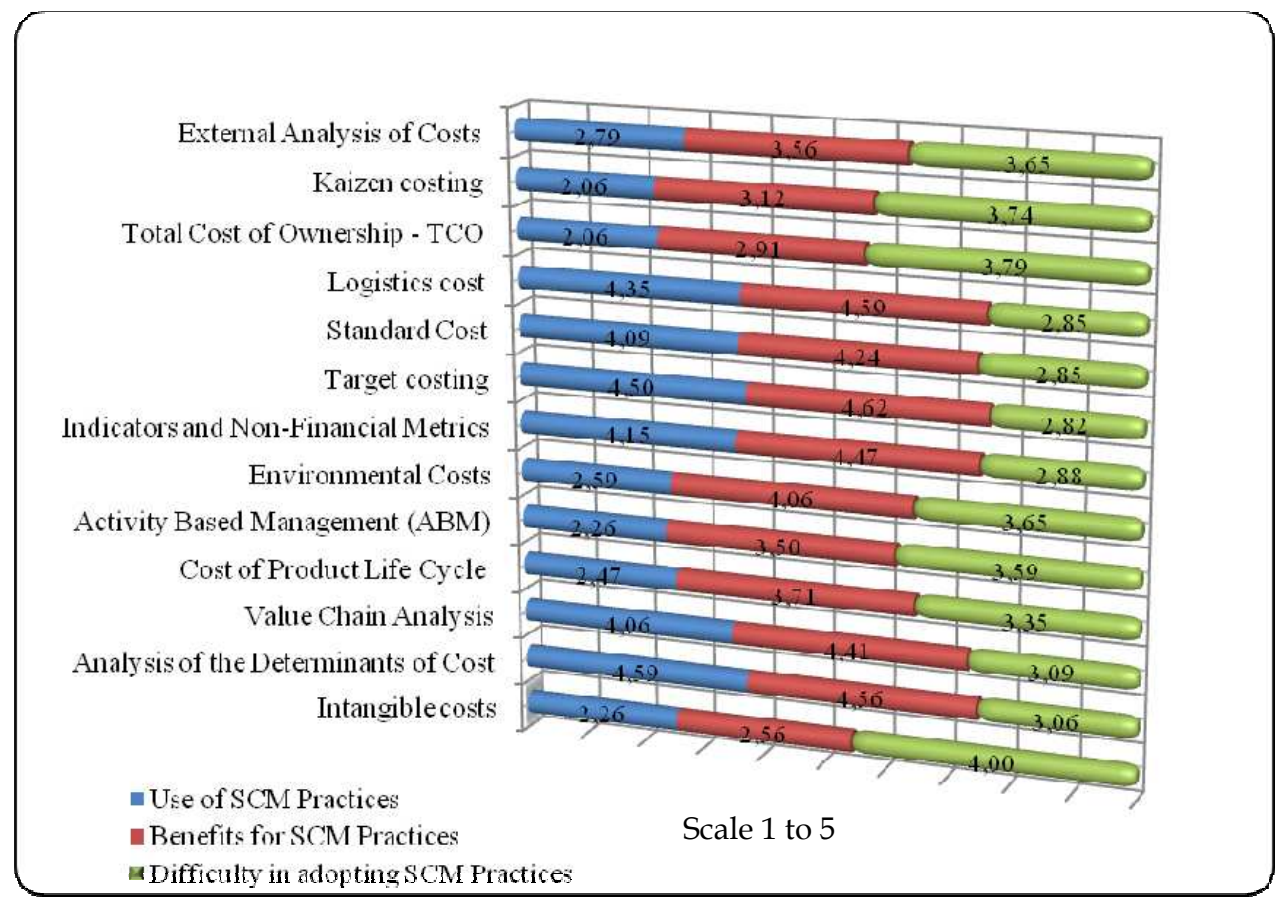

Source: Research Collected Data

Fig. 4. Average Degree of the Usage, Benefits and Difficulties in Adopting SCM Practices.

As shown in Figure 4, seven SCM practices have low adoption and great difficulties in implementation and usage (external analysis, kaizen costing, TCO, environmental costs, activity based management, life cycle costs and intangible costs). Despite the low utilization, the potential and the benefits are recognized, however, the exception is the practice of intangible costs. The low use of the environmental cost practice, ponders Gonçalves (2008), reveals the weakness of management given the international demands on environmental issues. The low adoption of the practice of activity based management, despite the benefit emphasized by literature, suggests that it is not noticed by managers. The same occurs with other practices such as life cycle costs, TCO, kaizen and analysis of external costs.

From the perception of $97 \%$ of respondents there are benefits in the usage of non-financial indicators. The benefits of using the standard cost reaches $88 \%$ in the total "high" and "very high". Blocher et al (2007) believe that these two practices may be associated by the reason that non-financial measures should be associated with costs for the control of strategic activities. The shown benefits by kaizen costing are noticed by $41 \%$ of respondents, although the adoption for this practice is only frequently used by $15 \%$ of companies. However, for the target costing both the noticed benefits and the frequent usage by businesses have high 
percentages. Eldenburg and Wolcott (2007) consider that the kaizen costing is similar to the target costing by setting goals to reduce costs. Still, the cost reduction goals are established to manage the downward trend in sale prices over the life cycle of products, given the value chain perspective. It is appropriate, in this context, the use of the kaizen costing (production stage) with the target costing (planning stage).

The benefits of the logistics costs practice are noticed by $97 \%$ of respondents as high and with the same percentage of frequent usage. The practice of environmental costs is often used by only $18 \%$ of respondent companies. These findings suggest that there are difficulties in its use. It is known that sanitary restrictions may affect competitiveness of firms and the intangible benefits for the adoption of environmental management. Environmental certifications value products since their preparation does not occur at the expense of environmental resources. The adoption of the practice of environmental cost management, in this background of requirements and benefits, might enable the companies highlight the investments made in benefits of society in this aspect. The low adoption of important SCM practices, though readily recognized its importance, can be credited to a number of difficulties encountered by companies. Among the difficulties, there is lack of qualified personnel and restructuring of procedures and system costs for companies. The main identified benefits are cost reduction, improvement in decision making and competitiveness.

The Pearson correlation coefficients, Table 2, indicate that SCM practices are positively related to the level of competition. However, as the coefficients are between 0.4 and 0.69 , the existing association is moderate (Gageiro and Pestana, 2005).

\begin{tabular}{|l|c|c|c|}
\hline SCM Practices & $\begin{array}{c}\text { Level of } \\
\text { Competition }\end{array}$ & $\begin{array}{c}\text { Competitive } \\
\text { Strategy }\end{array}$ & $\begin{array}{c}\text { Capital } \\
\text { Structure }\end{array}$ \\
\hline Cost of Product Life Cycle & $0,549^{* *}$ & 0,040 & $-0,091$ \\
\hline Activity Based Management (ABM) & $0,596^{* *}$ & 0,057 & $-0,090$ \\
\hline Environmental Costs & $0,628^{* *}$ & 0,043 & $-0,147$ \\
\hline Total Cost of Ownership - TCO & $0,475^{* *}$ & 0,296 & $-0,321$ \\
\hline Kaizen costing & $0,593^{* *}$ & 0,133 & $-0,329$ \\
\hline
\end{tabular}

Source: Research Collected Data

$(* *)$ Significance $(p$ value $<0.005)$

Table 2. Correlation - SCM Practices x Competition, Strategy and Capital Structure

The correlation between the SCM practices and the level of competition occurs in the low used practices by companies. For these practices, as evidenced in Table 1, there are greater difficulties for their implementation, despite the perception of potential benefits arising from their use. Such findings suggest the company that additional efforts justify the use of these practices. The Pearson correlation test identified no significant correlation between the use of the practices of SCM and capital structure (open / closed). The coefficients, negative, below 0.329 for all analyzed practices and statistically insignificant ( $p$ value $<0.005$ ). Regarding SCM practices and Competitive Strategy, the coefficients of correlation - positive - less than 0.296 and statistically not significant ( $p$ value $<0.005$ ) indicate no correlation. The lack of connection between these factors can be explained by similarity of firms on the size and experience, but can also be a feature of the segment. 
The ANOVA test, Table 3, was conducted to determine whether there are differences between the intensity on the noticed benefits arising from the practices of SCM and the different magnitude of exportation, having as proxy the "percentage of exports on turnover" of companies (size). The results for the SS show the main effects, with $p$ value $<0.001$, indicating that the probability of occurrence by chance is less than $0.01 \%$. The F value, which tests the equality of variances, is represented by the ratio between AS (x) and AS(error). The importance of calculating the $\mathrm{F}$ value is due to the analysis of the significance of the variances between the means.

\begin{tabular}{|c|c|c|c|c|c|c|}
\hline \multicolumn{2}{|c|}{$\begin{array}{c}\text { SCM Practices } x \text { Percentage of Exportation } \\
\text { without Turnover }\end{array}$} & $\begin{array}{c}\text { Sumo f } \\
\text { squares } \\
\text { (SS) }\end{array}$ & $\begin{array}{c}\text { Degrees of } \\
\text { freedom } \\
\text { (DF) }\end{array}$ & $\begin{array}{c}\text { Average of } \\
\text { Squares } \\
\text { (AS) }\end{array}$ & F & Sig. \\
\hline \multirow{2}{*}{$\begin{array}{c}\text { Activity Based } \\
\text { Management (ABM) }\end{array}$} & Between Groups (x) & 13,567 & 5 & 2,713 & 5,088 & 0,002 \\
\cline { 2 - 7 } & Inside Groups (error) & 14,933 & 28 & 0,533 & & \\
\cline { 2 - 7 } Target costing & Total & 28,500 & 33 & & & \\
\hline & Between Groups (x) & 6,963 & 5 & 1,393 & 5,518 & 0,001 \\
\cline { 2 - 7 } & Inside Groups (error) & 7,067 & 28 & 0,252 & & \\
\cline { 2 - 7 } & Total & 14,029 & 33 & & & \\
\hline \multirow{3}{*}{ Logistics Cost } & Between Groups (x) & 4,802 & 5 & 0,960 & 4,949 & 0,002 \\
\cline { 2 - 7 } & Inside Groups (error) & 5,433 & 28 & 0,194 & & \\
\cline { 2 - 7 } & Total & 10,235 & 33 & & & \\
\hline
\end{tabular}

Source: Research Collected Data

Table 3. ANOVA Test: Benefits x Percentage of Exportation without Turnover.

Based on scale of F Distribution, the critical value for 5 DF (numerator) and 28 DF (denominator) corresponds to $2.56(\mathrm{~F})$. Since the F values exceed this limit: 5.088 for the ABM; 5.518 for target costing, and 4.949 for the logistics costs, then the differences for these groups in terms of exportation variable is significant for a $\mathrm{p}$ value $<0.005$.

The differences in the ANOVA for companies that export, indicate relatively higher average about the perceived benefits. This suggests that management emphasizes logistics costs control as consumer markets are more distant. The benefit of target costing is outstanding in the exporting companies, given the limit of allowable costs to compete in these markets. The use of ABM is justified as it enables the implementation of other SCM practices: the use of the life cycle cost practice makes it necessary to check the activities of design, production, distribution, consumption and disposal. If it is the practice of environmental costs there will be are control activities (prevention, assessment), and the related lack of control ones (internal and external failure) analyzed.

Practices $\mathrm{ABC} / \mathrm{ABM}$, according to literature, are also needed in coordinating activities in the value chain for demonstrating the links among the needs, identifying opportunities for resource optimization and quality improvement (Porter (1998). In the analysis of perceived difficulties was applied Pearson's correlation test, as shown in Table 4. It was identified some relation in the degree of difficulty perceived by managers for implementation of the SCM practices.

The correlation coefficient of the difficulty level of implementation of kaizen costing indicates a strong association (between 0.70 and 0.89 ) with the level of difficulty of the TCO 
practice; other practices have a moderate association (between 0.40 and 0.69 ). For Pestana and Gageiro (2005), R (linear association) less than 0.20 is very low; between 0.20 and 0.39 low; between 0.40 and 0.69 moderate; between 0.70 and 0.89 high and finally, between 0.90 and 1.00 very high. For all variables, the significance $(p$ value $<0.005)$ indicates that the probability of the associations being by chance is smaller than $5 \%$. As example of the analysis regarding the level of competition, the results indicate practices of little use: the environmental cost, $\mathrm{ABC} / \mathrm{ABM}$ and kaizen costing.

\begin{tabular}{|l|c|c|c|c|c|}
\hline $\begin{array}{l}\text { Difficulties in } \\
\text { Implementing SCM } \\
\text { Practices }\end{array}$ & Target costing & $\begin{array}{c}\text { Analysis of the } \\
\text { Determinants } \\
\text { of Cost }\end{array}$ & $\begin{array}{c}\text { Indicators and } \\
\text { Non-Financial } \\
\text { Metrics }\end{array}$ & $\begin{array}{c}\text { Cost of Product } \\
\text { Life Cycle }\end{array}$ & $\begin{array}{c}\text { Total Cost of } \\
\text { Ownership - } \\
\text { TCO }\end{array}$ \\
\hline Standard Cost & $0,644^{*+}$ & - & - & - & - \\
\hline $\begin{array}{l}\text { Indicators and Non- } \\
\text { Financial Metrics }\end{array}$ & $0,493^{*+}$ & - & - & - & - \\
\hline Environmental Costs & $0,479^{*+}$ & - & - & - & - \\
\hline Logistics cost & $0,661^{*+}$ & $0,494^{*+}$ & $0,478^{*+}$ & - & - \\
\hline Value Chain Analysis & - & $0,555^{*+}$ & - & - & - \\
\hline ABC/ABM & - & - & - & $0,663^{*+}$ & - \\
\hline Kaizen Costing & - & - & - & - & $0,846^{*+}$ \\
\hline
\end{tabular}

Source: Research Collected Data

Table 4. Pearson's correlation test - Noticed Difficulties in SCM Practices.

\subsection{General Interpretation of data analysis}

An overview of the analysis' findings shows that there is a balance between use and nonuse of the SCM practices surveyed. From the total of 13 practices surveyed, six of them $(46.2 \%)$ are well used and the remaining have limited use. At first glance this ratio suggests an overall unfavorable scenario, however, the adoption identified in this study is greater than in other national surveys and lower than the international ones.

Although there is present emphasis on cost management literature, it draws attention the low usage of $A B C$ and $A B M$. In this context, it is plausible the recent simplification of the $\mathrm{ABC}$ under the guise of TDABC. Literature also tends to emphasize that it is antagonistic the use of standard cost practices and target costing (Shank and Govindarajan, 1997). However, the survey results show the opposite, suggesting that the surveyed companies have managed to separate the utility of practices in the stages of planning and cost control, making them complementary. Finally, special attention should be given to the results of the correlation tests [Pearson and ANOVA], which did not identify common characteristics of companies with the degree of correlation that indicates a situation with force to leverage the use of SCM practices listed in this research.

\section{Closing remarks}

The focus of the study was to investigate the use, the importance of perceived benefits and difficulties of implementation by agribusiness companies of SCM practices, treated in the literature as the most appropriate ones to help managers in the management process of organizations. In summary, the findings on practices of SCM show heavier usage of six practices among the 13 listed. The benefits, limitations and disadvantages from the use of 
practices deserve to be highlighted for the paradoxical situation of high importance, low utilization and high difficulty degree of implementation found by some. The level of competition has no importance in the adoption of practices, nor the capital structure (open/closed) has relation to the type of strategy used.

Although the findings of this research cannot be generalized, it is displayed two major impacts. The impact to the academy is the challenge to rethink the contents of the subjects related to cost, managerial and strategic accounting. It is understood that the dissemination of knowledge must occur as an undergraduate, as addition for the student when in full professional activity. On the other hand, the impact for practitioners is to seek to overcome the conceptual shortcomings over SCM practices, to act as disseminators of knowledge in their organizations and show the benefits to the organization for its use.

Finally, during the study it was evidenced the need for more specific and accurate studies in terms of non-use of SCM practices given strong indications in literature. We believe that the findings of this exploratory study provide the foundation for conducting researches in the form of multiple case study and cross-case analysis. The results of investigations with these approaches may indicate - with more direct and objective responses to deal with issues, sometimes paradoxical - relation to the benefits and difficulties in implementation and use of SCM practices addressed in this research.

\section{References}

Angelakis, George; Theriou, Nikolaos; Floropoulos, Jordanis. ( 2010). Adoption and benefits of management accounting practices: evidence from Greece and Finland. Advances in Accounting, v. 26, n. 1, p. 87-96.

Anthony, Robert, N.; Govindarajan, Vijav. (2008). Sistemas de controle gerencial. 12a ed. São Paulo: Atlas.

Azevedo, Paulo F. (2010). Comercialização de produtos agroindustriais. In: BATALHA, Mario Otávio. Gestão agroindustrial. $3^{\mathrm{a}}$ ed. São Paulo: Atlas, p. 63-112.

Babbie, Earl. (2005). Métodos de pesquisas de survey. Belo Horizonte: Ed. UFMG.

Bacic, Miguel Juan. (1994). Escopo da gestão estratégica de custos em face das noções de competitividade de estratégia empresaria. In:CONGRESSO BRASILEIRO DE GESTÃO ESTRATÉGICA DE CUSTOS, 1. Anais Eletrônicos... São Leopoldo: ABCustos.

Bacic, Miguel Juan. (2009). Gestão de custos. Curitiba: Juruá.

Banco Nacional De Desenvolvimento Econômico E Social - Bndes. (2010). Porte de empresas. Disponível em:

http://www.bndes.gov.br/SiteBNDES/bndes/bndes_pt/Navegacao_Suplementa r/Perfil/porte.html. Acesso em: 25 jan 2011.

Batalha, Mario Otávio; Silva, Andre Lago. (2010). Gerenciamento de sistemas agroindustriais: definições, especificidades e corrente metodológicas. In: BATALHA, Mario Otávio. Gestão Agroindustrial. $3^{a}$ ed. São Paulo: Atlas, p. 1-60.

Blocher, Edward J.; Chen, Kung H.; Cokins, Gary; Lin, Thomas W. (2007). Gestão estratégica de custos. São Paulo: McGraw-Hill.

Bowhill, Bruce; Lee, Bill. (2002). The incompatibility of standard costing systems and modern manufacturing. Journal of Applied Accounting Research, v.6, n.3, p.1-24. 
Cadez, Simon; Guilding, Chris. (2007). Benchmarking: the incidence of strategic management accounting in Slovenia. Journal of Accouting \& Organizational Change, v.32, n.2, p.126-146.

Callado, Antônio A. C.; Callado, Aldo L. C. (2006). Mensuração e controle de custos: um estudo empírico em empresas agroindustriais. Sistemas \& Gestão Revista Eletrônica, v. 1, n. 2, p.132-141.

Callado, Antonio A. C.; Moraes Rodolfo A. (2009). Gestão de custos no agronegócio. In: CALLADO, Antonio A. C. Agronegócio. $2^{\mathrm{a}}$ ed. São Paulo: Atlas, p. 20-28.

Carastan, Jacira T. (1999). Custo-meta e custo-padrão como instrumentos do planejamento empresarial para obter vantagem competitiva. In: CONGRESSO BRASILEIRO DE CUSTOS. 6. São Paulo. Anais eletrônicos... São Paulo: ABCustos.

Cinquini, Lino.; Tenucci, Andrea. (2006). Strategic management accounting: exploring links with strategy. Disponível em: http://www.unisanet.unisa.edu.au/Resources/.../ Cinquini \%20\&\%20Tenucci.pdf. Acesso em: $20 \mathrm{dez} 2010$.

Confederação Nacional Da Agricultura E Pecuaria Do Brasil - Cna. 2010. Site institucional. Disponível em:< http:/ / www.canaldoprodutor.com.br/> Acesso em: 15 dez 2010.

Conselho Nacional De Segurança Alimentar E Nutricional - Consea. 2008. Exposição de motivos. Disponível em: <https://www.planalto.gov.br/Consea/exec/index.cfm>. Acesso em: 06 Jan. 2011.

Cyrillo, Fabio. (2010). Novas demandas do varejo. In: CONGRESSO NACIONAL DE GESTÃO DO AGRONEGÓCIO, 1. Chapecó. Anais eletrônicos... Chapecó: Agrogestão.

Davis, John.; Goldberg, Ray. (1957). The genesis and evolution of agribusiness. In: Davis, J.; Goldberg, R. A concept of agribusiness. Harvard University, p.4-6.

DE ZOYSA, Anura; HERATH, S. Kanthi. (2007). Standard costing in Japanese firms. Industrial Management \& Data Systems, V.107, N.2, P. 271-283.

Dekker, Henri; Smidt, Peter. (2003). A Survey of the adoption and use of target costing In Dutch firms. International Journal Of Production Economic, v. 84, n.3, p.293-305.

Eldenburg, Leslie G.; Wolcott, Susan K. (2007). Gestão de custos: como medir, monitorar e motivar o desempenho. Rio de Janeiro: LTC.

Fischmann, Adalberto A.; Zilber, Moisés A. (2001). Utilização de indicadores de desempenho como instrumento de suporte à gestão estratégica. RAM, v.1, n.1, p. 925.

Frost, Bob. (1999). Performance metrics. Strategy and Leadership, v. 27, p.34-36.

Gasques, José G.; Rezende, Gervásio C.; Verde, Carlos M. V.; Conceição, Júnia Cristina P. R.; CARVALHO , João C. S.; SALERNO, Mario S. (2004). Desempenho e crescimento do agronegócio no Brasil. Disponível em:http://www.ipea.gov.br/portal/ images/stories/PDFs/TDs/td_1009.pdf Acesso em: 20 jan 2011.

Gil, Antonio Carlos. (2002). Como elaborar projetos de pesquisa. São Paulo: Atlas.

Gonçalves, José A. (2008). Os bons exemplos que vem do campo. In: Anuário Exame Agronegócio: Ranking das 400 maiores empresas do agronegócio. São Paulo: jun, p.54-57.

Guilding, Chris; Cravens, Karen S.; Taykes, Mike. (2000). An international comparison of strategic management accounting practices. Management Accounting Research, v.11, n.1, p. 113-135.

Hansen Don R; Mowen, Maryanne M. (2001). Gestão de custos. São Paulo: Pioneira. 
Instituto Interamericano De Cooperação Da Agricultura - Iica. Caderno de estatísticas do agronegócio. 2009. Disponível em:

http:HTTP:/ / www.iica.org.br/Docs/Publicacoes/Agronegocio/CadernoEstatistic as_03-009.pdf Acesso em: $10 \mathrm{dez} 2010$.

Jackson, Anthony; MITCHELL Eve. (2009). Food sovereignty: time to choose sides. Encyclopaedia Britannica. Disponível em: http://media.web.britannica.com/ ebsco/pdf/37/37221176.pdf Acesso em: 04 mai 2010.

Johnson, H. Thomas; KAPLAN, Robert S. (1987). Relevance lost: the rise and fall of management accounting. Boston: HBSP.

Johnson, H. Thomas. (1992). Relevance regained: from top-down control to bottom-up empowerment. New York: Free Press.

Kaplan, R. S.; Norton, D. P. (1997). A Estratégia em ação. Rio de Janeiro: Campus.

Kaplan, Robert \& Cooper, Robin. (1998). Custo \& desempenho. São Paulo: Futura.

Kotler, P. (1998). Administração de marketing São Paulo: Atlas.

Lima, Fátima M. S.; Abrantes, Luiz A. A.; Correia, Laura F. M.; Brunozi Jr., Antonio C. (2009). Políticas públicas de inovação tecnológica na cadeia agroindustrial do leite: o efeito da instrução normativa $n^{\circ} 51$ nos produtores rurais da Microrregião de Viçosa, MG. In: ENANPAD, 33. Anais... São Paulo, ANPAD.

Loturco, Roseli. (2008). Os obstáculos para as multinacionais do agro. In: Anuário Exame Agronegócio: Ranking das 400 maiores empresas do agronegócio. São Paulo: p.2123.

Marques, J.; Skorupa, L. A.; Ferraz, José M. G.; Bacellar, A. A. (2003). Indicadores de sustentabilidade em agro-ecosystems. Jaguariúna: Embrapa Meio Ambiente.

Miles, Raymond E.; Snow, Charles C. (1978). Organizational strategy, structure and process. New York: Mc Graw-Hill.

Muniz, Luciani Silva. (2010). Práticas de gestão estratégica de custos adotadas por empresas brasileiras. Dissertação (Mestrado em Ciências Contábeis). Unisinos. São Leopoldo.

Nakagawa, Masayuki. (1991). Gestão estratégica de custos. São Paulo: Atlas.

nascimento, auster m.; reginato, luciane; lerner, Daiane F. (2007). Avaliação de desempenho organizacional. In: NASCIMENTO, Auster Moreira; Reginato, Luciane (Org). Controladoria: um enfoque eficácia organizacional. São Paulo: Atlas, 2009.

Noordin, R. Zainuddin, Yuserrie; Tayles, Michael. (2009). Strategic management accounting information elements. Management Accounting Journal, v.4, n.1, p.17-34.

Oliveira, Deyvison L.; Pereira, Sidinei A. (2008). Análise do processo decisório no agronegócio. Revista Eletrônica Gestão e Sociedade, v.2, n.4, p.1-24.

Pestana, Maria H.; Gageiro, João N. (2005) Análise de dados para ciências sociais: a complementaridade do SPSS. Lisboa: Edições Silabo, Lda.

Porter, Michael E. (1986). Estratégia competitiva. Rio de Janeiro: Campus.

Porter, M. E. (1989) Vantagem competitiva. Rio de Janeiro: Campus.

Queiroz, Timóteo Ramos. (2006). Ferramentas de controle da inovação na propriedade rural. In: Agronegócios gestão e inovação. (Org) Zuin, Luís Fernando S.; QUEIROZ, Timóteo R. Cap.10. São Paulo: Saraiva.

Reckziegel, Valmor; Souza, Marcos A.; Diehl, Carlos A. (2007). Práticas de gestão adotadas por empresas estabelecidas nas Regiões Noroeste e Oeste do Paraná. Revista Brasileira Gestão de Negócios, v. 9, n. 23, p.14-27. 
Rocha, Welington. (1999). Contribuição ao estudo de um modelo conceitual de sistema de gestão estratégica.Tese (Doutorado em Controladoria e Contab.) - FEA/USP, São Paulo.

Roesch, Sylvia Maria Azevedo. (2005). Projetos de estágio e de pesquisa em administração guia para estágios, trabalhos de conclusão, dissertações e estudos de caso. São Paulo: Atlas.

Shank, J.K.; Govindarajan, V. (1997). A revolução dos custos. R. Janeiro: Elsevier.

Silva, Andre L.; Batalha, Mario O. (2010) Marketing estratégico aplicado ao agronegócio. In: Batalha, Mario Otávio. Gestão agroindustrial. São Paulo: Atlas, p. 1-60.

Silva, E. L.; Menezes, E. M. Metodologia da pesquisa e elaboração de dissertação. $3^{\circ}$. ed. Florianópolis: Laboratório de Ensino a Distância da UFSC, 2001.

Simmonds, K. (1981) Strategic management accounting. Management Accounting, april, p. 26-9

Sobral, Eliane. Mais dinheiro no campo. (2008). In: Anuário Exame Agronegócio: Ranking das 400 maiores empresas do agronegócio, p. 90-92. São Paulo.

Souza, Marcos A.; Collaziol, Elisandra; Damacena, Cláudio. (2010). Mensuração e registro dos custos da qualidade: uma investigação das práticas e da percepção empresarial. RAM, v.11, n. 4, p.66-97.

Thorpe J.; Prakash-Mani, K. (2003). Developing value the business case for sustainability in emerging markets. Greener Management International, v.44, p. 17-32.

Vilckas, Mariângela; Nantes, José F. D. (2006). Planejamento e agregação de valor nos empreendimentos rurais. In: ZUIN, Luiz F. S.; QUEIROZ, Timóteo R. Agronegócios gestão e inovação. São Paulo: Saraiva, p.167-188.

Waweru, N. M.; Hoque, Z.; Uliana, E. (2005). A Survey of management accounting practices in South Africa. National Journal of Accounting, Auditing and Performance Evaluation, v.2, n.3, p.226-263.

Zuin, L. F. S.; Queiroz, T.R. (2006). Agronegócios gestão e inovação. São Paulo: Saraiva. 


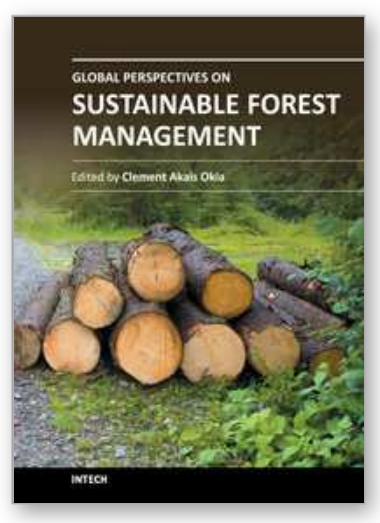

\author{
Global Perspectives on Sustainable Forest Management \\ Edited by Dr. Dr. Clement A. Okia
}

ISBN 978-953-51-0569-5

Hard cover, 300 pages

Publisher InTech

Published online 25, April, 2012

Published in print edition April, 2012

This book is dedicated to global perspectives on sustainable forest management. It focuses on a need to move away from purely protective management of forests to innovative approaches for multiple use and management of forest resources. The book is divided into two sections; the first section, with thirteen chapters deals with the forest management aspects while the second section, with five chapters is dedicated to forest utilization. This book will fill the existing gaps in the knowledge about emerging perspectives on sustainable forest management. It will be an interesting and helpful resource to managers, specialists and students in the field of forestry and natural resources management.

\title{
How to reference
}

In order to correctly reference this scholarly work, feel free to copy and paste the following:

Marcos Antonio Souza and Kátia Arpino Rasia (2012). Strategic Cost Management Practices Adopted by Segments of Brazilian Agribusiness, Global Perspectives on Sustainable Forest Management, Dr. Dr. Clement A. Okia (Ed.), ISBN: 978-953-51-0569-5, InTech, Available from: http://www.intechopen.com/books/globalperspectives-on-sustainable-forest-management/strategic-cost-management-practices-adopted-by-segmentsof-brazilian-agribusiness

\section{INTECH}

open science | open minds

\section{InTech Europe}

University Campus STeP Ri

Slavka Krautzeka 83/A

51000 Rijeka, Croatia

Phone: +385 (51) 770447

Fax: +385 (51) 686166

www.intechopen.com

\section{InTech China}

Unit 405, Office Block, Hotel Equatorial Shanghai

No.65, Yan An Road (West), Shanghai, 200040, China

中国上海市延安西路65号上海国际贵都大饭店办公楼405单元

Phone: +86-21-62489820

Fax: $+86-21-62489821$ 
(C) 2012 The Author(s). Licensee IntechOpen. This is an open access article distributed under the terms of the Creative Commons Attribution 3.0 License, which permits unrestricted use, distribution, and reproduction in any medium, provided the original work is properly cited. 